$$
\begin{gathered}
\text { THE LAST DAYS } \\
\text { OF THE JERUSALEM } \\
\text { OF LITHUANIA }
\end{gathered}
$$





\title{
THE LAST DAYS
}

OF THE JERUSALEM

O F LITHUANIA

Chronicles from the Vilna Ghetto

\author{
and the Camps, 1939-I944
}

HERMAN KRUK

EDITED AND INTRODUCED

BY BENJAMIN HARS HAV

TRANSLATED BY BARBARA HARSHAV

YIVO INSTITUTE FOR JEWISH RESEARCH

YALE UNIVERSITY PRESS

NEW HAVEN AND LONDON

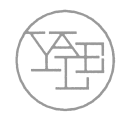


Published with assistance from the Nusach Vilne Society

Yiddish diary and English-language translation copyright (C) 2002 by YIvo Institute for Jewish Research. Preface, introduction, and compilation of this edition copyright (C) 2002 by Benjamin Harshav.

$$
\text { All rights reserved. }
$$

This book may not be reproduced, in whole or in part, including illustrations, in any form (beyond that copying permitted by Sections I07 and Io8 of the U.S. Copyright Law and except by reviewers for the public press), without written permission from the publishers.

Set in ITC Charter type by The Composing Room of Michigan, Inc. Printed in the United States of America by R. R. Donnelley \& Sons.

Library of Congress Cataloguing-in-Publication Data Kruk, Herman, I897-I944.

[Togbukh fun Vilner geto. English]

The last days of the Jerusalem of Lithuania : chronicles from the Vilna ghetto and the camps, I939-I944 / Herman Kruk ; edited and introduced by Benjamin Harshav ; translated by Barbara Harshav.

p. $\mathrm{cm}$.

Includes bibliogaphical references and index. ISBN 0-300-04494-I (alk. paper)

I. Kruk, Herman, 1897-I944. 2. Jews-Persecutions-Lithuania-Vilnius. 3. Holocaust, Jewish (1939-I945)—Lithuania—Vilnius—Personal narratives. 4. World War, I939- 1945-Jewish resistance-Lithuania—Vilnius. 5. Vilnius (Lithuania)—Ethnic relations. 6. Klooga (Concentration camp) 7. Concentration camps-Estonia.

I. Harshav, Benjamin, I928- II. Title.

$$
\begin{gathered}
\text { DSI35.L52 V5548I3 } 2002 \\
\text { 940.53' } 18 \text { ' 092-dc2I } \\
\text { [в] } 2002016736
\end{gathered}
$$

A catalogue record for this book is available from the British Library.

The paper in this book meets the guidelines for permanence and durability of the Committee on Production Guidelines for Book Longevity of the Council on Library Resources.

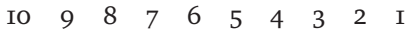

Unless otherwise noted, all illustrations appear courtesy of the YIVo Institute for Jewish Research.

Yale University Press would like to acknowledge the invaluable assistance of Donald J. Cohen (1940-200I), former director of the Yale Child Study Center and chairman of the Committee on Publications of Yale University Press. Without his unflagging support, the publication of this book would not have been possible. 
[In September 1943, the Vilna Ghetto was liquidated and several thousand remaining Jews, including Herman Kruk, were transported to camps in Estonia, notably to Klooga, near Tallinn. Kruk continued writing his chronicle-in the form of diaries, narratives, and poems - up to the last day. He was killed and burned with most of the surviving Jews just hours before the Red Army liberated the area on September I9, 1944. The following poem, written in Yiddish in precise amphibrachic meter, was found among his writings from this last period and is presented here in a literal translation.]

FOR FUTURE GENERATIONS

Neighbors in Camp Klooga often ask me Why do you write in such hard times?Why and for whom? ...

... For we won't live to see it anyway.

I know I am condemned and awaiting my turn, Although deep inside me burrows a hope for a miracle.

Drunk on the pen trembling in my hand, I record everything for future generations: A day will come when someone will find The leaves of horror I write and record. People will tear their hair in anguish, Eyes will plunge into the sky Unwilling to believe the horror of our times. And then these lines will be a consolation For future generations, which I, a prisoner, Kept in my sight, things I recorded, fixed faithfully. . . . For me it is superfluous, For future generations I leave it as a trace. And let it remain though I must die here And let it show what I could not live to tell. And I answer my neighbors:

Maybe a miracle will liberate me.

But if I must die, it must not die with me- 
The time of horrors I leave for future worlds.

I write because I must write-a consolation in my time of horror.

For future generations I leave it as a trace.

-March 24, 1944 
[The following note was found with Kruk's papers, hidden in the ruins of the Vilna Ghetto.]

TO THOSE WHO MAY FIND THIS MATERIAL!!

The materials gathered here-the chronicle along with all the documents, manuscripts, and other texts—-were collected, written, and preserved in the most difficult days of my life, from I94I to April 1943.

I beg the honest discoverer to respect my wish, preserve the materials, and carefully ship them to my friends or relatives. 
